\title{
Metal Cations Analysis Contained in Sambucus ebulus L., by Comparative Methods of Atomic Absorption Spectrometry
}

\author{
ADINA MAGDALENA BUNGET ${ }^{1}$, MICHAEL SCHENKER ${ }^{2 *}$, ALIN DRAGOS DEMETRIAN², AUREL GHERGHINA ${ }^{3}$, LUCRETIU RADU², \\ LIVIU CHIRIGIU4 ${ }^{4}$, ANA CELLA ANDREI ${ }^{5}$ \\ UUniversity of Medicine and Pharmacy of Craiova, Faculty of Dentistry, 2 Petru Rares Str., 200638, Craiova, Romania \\ 2University of Medicine and Pharmacy of Craiova, Faculty of Medicine, 2 Petru Rares Str., 200638, Craiova, Romania \\ ${ }^{3}$ Ministry of National Defence, 13-15 Izvor Str., 050561, Bucharest, Romania \\ ${ }^{4}$ University of Medicine and Pharmacy of Craiova, Faculty of Pharmacy, 2 Petru Rares Str., 200638, Craiova, Romania \\ ${ }^{5}$ Carol Davila University of Medicine and Pharmacy Bucharest, Faculty of Dental Medicine,Calea Plevnei, 050051, Bucharest, \\ Romania
}

\begin{abstract}
The purpose of this study was to perform a comparative study of cations in the vegetative organs of Sambucus ebulus by applying three different methods of digestion before atomic absorption spectrometry. Of the tested methods, the most effective was method 3 (mineralisation with nitric acid in a microwave oven), the other methods of sample digestion leading to incomplete mineralization of the samples and implicitly to the incomplete transfer of the analytes into solution, reflecting the slightly different contents in metal cations we obtained.
\end{abstract}

Keywords: Sambucus ebulus L., atomic absorbtion spectrometry, digestion

There is a lot of research on spontaneous flora in order to determine on the one hand the contained secondary metabolites $[1,2,3]$ and on the other hand their curative properties or antimicrobial properties.

Although in our country the curative potential of Sablucus ebulus $L$ is relatively unknown, other countries like Turkey and Iran pay special attention to this species.

Thus, references in the literature appear regarding the use of leaves, flowers and fruits as expectorant, diuretic or purgativ, the leaves being used separately in various inflammatory conditions such as rheumatoid arthritis, fever, pulmonary edema, burns or various open wounds[4].

How ever, the extracts or phytopharmaceutical products obtained from the leaves of the species mustbe consumed with moderation because they contain cianogenic heterosides, compounds known for their high toxicity.

There are several authors who analyzed the antiinflammatory activity of Sambucus ebulus leaves and fruits using laboratory animals [5]. Methanol and n-hexane extracts showed an anti-inflammatory activity as high as diclofenac [6]. The extract from the strains of the species had a similar effect to sodium salicylate [7].

The mechanisms of action for the extracts proposed by the authors were those of inhibiting COX (cyclooxygenase) activity, thereby diminishing pain and inflammation [8]. Other authors have put antitumoral and antiangiogenic effect on ebulithin 1, this immunotoxin having antineoplastic effects on cell lines L929, L6E9, CD105 [9]. It is considered necessary to determine the metal cations in plants with possible therapeutic uses given that by their consumption (in various pharmaceutical forms).

If some cations are beneficial and help to meet nutritional requirements, others, on the contrary, have toxic effects on the human body [10].

Various methods have been used for these determinations over the years [11], but in the last decade numerous scientific quantification studies have emerged in metallic cations by atomic absorption spectrometry using various ways of pre-sample preparation [12]. In this study, atomic absorption spectrometry with flame or graphite furnace was used as a method for determining metallic cations. Several working methods have been applied for further comparative analysis.

\section{Experimental part}

Materials and methods

Sample harvesting

The plants were harvested from Simnicu de Sus, Dolj County. Then, the plants were naturally dried at temperatures between $20-25^{\circ} \mathrm{C}$ in a dark room. During the drying, the percentage of lost water ranged between 10 and $18 \%$.

Dried plants, separated on vegetative organs, cleaned from potential impurities that could affect the results of the research (dust particles, impurities, and damaged matter) were ground in a stainless steel grinder.

\section{Samples mineralization}

In the three methods we performed, a different procedure of sample mineralization was used, either by initial calcination of the sample, followed by the digestion of the residue with nitric acid (method 2), or by subjecting the samples to the digestion process before calcinations (method 1 and 3). The digestion process has been achieved with concentrated nitric acid (method 1) or with a mixture of concentrated nitric acid and hydrogen peroxide (method 3).

For methods 1 and 2 the analysis was performed on an AA240FS DUO Varian apparatus, for method 3 a novAA 400G - Analyzer Jena with autosampler MPE60 and soft WinAAS 3.17.0 was used

\section{Method 1}

An amount of $0.5 \mathrm{~g}$ product was weighed into a teflon crucible. $5 \mathrm{~mL}$ of high purity concentrate nitric acid and 1 $\mathrm{mL}$ of $30 \%$ hydrogen peroxide were added over the samples. The samples thus obtained were mineralized in the MLS1200 Mega Milestone microwave oven using the following pow er program:

\section{2 min at $250 \mathrm{~W}$ \\ $2 \mathrm{~min}$ at $0 \mathrm{~W}$}

* email: mike_schenker@yahoo.com 
6 min at $250 \mathrm{~W}$

$5 \mathrm{~min}$ at $400 \mathrm{~W}$

5 min at $600 \mathrm{~W}$

The mineralized samples were quantitatively added in $50 \mathrm{~mL}$ sized flasks.

\section{Method 2}

For this method, the samples were weighed to the analytical balance directly in a calibrated crucible, then they were heated in an oven at $110-120^{\circ} \mathrm{C}$ when they lost the water, the volatile substances and a part of crystallization water. Further, we continued the heating at $180-200^{\circ} \mathrm{C}$, in order that organic substances with boiling temperatures below $180^{\circ} \mathrm{C}$ to leave the material.

After $60 \mathrm{~min}$, the crucible was removed from the oven and placed in a thermostated electric oven increasing the temperature from 50 to 50 degrees Celsius until it reached $500^{\circ} \mathrm{C}$ then the temperature was kept constant so that the sample reached a constant mass. During this time, calcination of organic substances takes place, which decompose into $\mathrm{CO}_{2}, \mathrm{H}_{2} \mathrm{O}$ and volatile compounds.

In general, the inorganic salts of the metal cations remain in the crucible. After cooling in the desiccator, the crucible was again weighed. Next, the residue obtained by calcination was quantitatively brought into solution with $50 \mathrm{~mL}$ of $14 \%$ nitric acid. For the solutions thus obtained, atomic absorbances were determined by a Varian 220 atomic absorption spectrometer. For each determined element a cavity cathode lamp made of spectral purity metal was used [13].

\section{Method 3}

Approximately $0.5 \mathrm{~g}$ of the samples were treated with $11 \mathrm{~mL}$ of $65 \%$ nitric acid and subjected to mineralization in a MWS 2-Berghof microwave oven using a three-step program: $\mathrm{T}_{1}=160^{\circ} \mathrm{C}, \mathrm{t}_{1}=15 \mathrm{~min}, \mathrm{p}_{1}=80 \%, \mathrm{~T}_{2}=210^{\circ} \mathrm{C}, \mathrm{t}_{2}$
$=15$ minutes, $p_{2}=90 \%$ and decreasing $\mathrm{T}_{3^{\prime}} \mathrm{t}_{3}=15$ minutes, $p_{3}=0 \%$.

${ }^{3}$ The mineralized samples were quantitatively added in $100 \mathrm{~mL}$ volumetric flasks and filled in with ultrapure water.

\section{Results and discussions}

1.

The results obtained using Method 1 are shown in Table

The concentrations of metal cations in the plant product obtained by Method 2 are shown in Table 2.

As it can be seen by studying the obtained results (fig. 1 ), incomplete mineralization of the samples leads to the incomplete transfer of the analytes into solution, reflecting the slightly different contents in metal cations we obtained.

Of the determined ions, calcium and magnesium are in the highest proportion, both are classified as macro elements, and among the trace elements, iron and zinc have been found in the largest quantities, regardless of the mineralization method chosen.

The amounts of zinc and iron found in this plant are comparable to the results from the literature [14-16], obtained for plants belonging to both the Sambucus genus [17-19] and other genres from Caprifoliaceae family [20], these being the microelements needed in high quantities to normal plant growth. The zinc-enhanced chemical composition of this species may involve certain hypoglycemiant properties [21].

Two unwanted cations associated with environmental pollution, $\mathrm{Pb}^{2+}$ and $\mathrm{Cr}^{3+}$, were found in Sambucus ebulus $\mathrm{L}$. The only parts where the content in these cations is higher or comparable are ripe fruit. However, the third cation present in the polluted areas, $\mathrm{Cd}^{2+}$ is present only in the leaves of the species [22].

The content of the mentioned cations can provide us with valuable informations on the composition of the anatomical parts of the plant in organic compounds that

Table 1

METAL CATIONS OF THE SPECIES Sambucus ebulus $L$ determined by method 1

\begin{tabular}{|c|c|c|c|c|c|c|c|c|}
\hline Sample & $\begin{array}{c}\mathrm{Ca} \\
(\mu \mathrm{g} / \mathrm{g})\end{array}$ & $\begin{array}{c}\mathrm{Fe} \\
(\mu \mathrm{g} / \mathrm{g})\end{array}$ & $\begin{array}{c}\mathrm{Mn} \\
(\mu \mathrm{g} / \mathrm{g})\end{array}$ & $\begin{array}{c}\mathrm{Mg} \\
(\mu \mathrm{g} / \mathrm{g})\end{array}$ & $\begin{array}{c}\mathrm{Zn} \\
(\mu \mathrm{g} / \mathrm{g})\end{array}$ & $\begin{array}{c}\mathrm{Pb} \\
(\mu \mathrm{g} / \mathrm{g})\end{array}$ & $\begin{array}{c}\mathrm{Cr} \\
(\mu \mathrm{g} / \mathrm{g})\end{array}$ & $\begin{array}{c}\mathrm{Ni} \\
(\mu \mathrm{g} / \mathrm{g})\end{array}$ \\
\hline fruits & $3196.9 \pm 0.46$ & $97.1 \pm 0.71$ & $16.4 \pm 32$ & $1698.6 \pm 25$ & $20.7 \pm 18$ & $1.47 \pm 14$ & $0.357 \pm 20$ & $2.57 \pm 29$ \\
\hline Stems & $2921.8 \pm 0.22$ & $9.9 \pm 0.42$ & $5.57 \pm 31$ & $2127.147 \pm 79$ & $6.2 \pm 0.70$ & $0.787 \pm 40$ & $0.157 \pm 09$ & $1.32 \pm 0.17$ \\
\hline Leaves & $9539.6 \pm 0.18$ & $148 \pm 0.55$ & $49.937 \pm 52$ & $54697 \pm 71$ & $23.127 \pm 69$ & $0.767 \pm 23$ & $1.377 \pm 14$ & $0.99 \pm 0.24$ \\
\hline Roots & $2805.1 \pm 0.62$ & $200.25 \pm 0.91$ & $37.1 \pm 0.76$ & $1841.22 \pm 24$ & $19.46 \pm 0.50$ & $0.7 \pm 0.99$ & $4.15 \pm 34$ & $7.146 \pm 80$ \\
\hline
\end{tabular}

\begin{tabular}{|c|c|c|c|}
\hline \multirow[t]{2}{*}{ Sample } & $\mathrm{Cu}$ & $\mathrm{Pb}$ & Zn \\
\hline & $\mathrm{C}_{\mathrm{A}}(\mu \mathrm{g} / \mathrm{g})$ & $\mathrm{C}_{\mathrm{A}}(\mu \mathrm{g} / \mathrm{g})$ & $\mathrm{C}_{\mathrm{A}}(\mu \mathrm{g} / \mathrm{g})$ \\
\hline Green fruits & $6.895 \pm 0.20$ & $1.021 \pm 0.27$ & $33.1 \pm 0.11$ \\
\hline Black fruits & $4.962 \pm 0.41$ & $0.728 \pm 0.98$ & $27.9 \pm 0.78$ \\
\hline Leaves & $1.923 \pm 0.43$ & $0.876 \pm 0.12$ & $47.5 \pm 0.29$ \\
\hline Roots & $6.310 \pm 0.34$ & $1.952 \pm 0.21$ & $26.5 \pm 0.16$ \\
\hline Stems & $7.374 \pm 0.54$ & $2.980 \pm 0.19$ & $35.6 \pm 0.26$ \\
\hline
\end{tabular}

Table 2

METAL CATIONS OF THE SPECIES Sambucus ebulus L DETERMINED BY METHOD 2 


\begin{tabular}{|c|c|c|c|c|c|c|}
\hline \multirow{2}{*}{ Sample } & \multicolumn{6}{|c|}{ Concentrația ( $\mu$ g/g) } \\
\cline { 2 - 7 } & Cd & Cu & Cr & Zn & Pb & Fe \\
\hline Fruits & $*$ & $2.34 \pm 0.09$ & $9.85 \pm 0.29$ & $45.92 \pm 0.93$ & $9.21 \pm 0.07$ & $113.40 \pm 0.35$ \\
\hline Leaves & $0.32 \pm 0.11$ & $5.16 \pm 0.70$ & $10.27 \pm 0.14$ & $36.58 \pm 1.06$ & $12.63 \pm 0.14$ & $99.29 \pm 0.24$ \\
& & & & & $*$ & $*$ \\
\hline Stems & $*$ & $2.16 \pm 0.34$ & $*$ & $16.58 \pm 0.96$ & $*$ & \\
\hline
\end{tabular}

Tabel 3

METAL CATIONS OF THE SPECIES Sambucus ebulus L DETERMINED BY METHOD 3

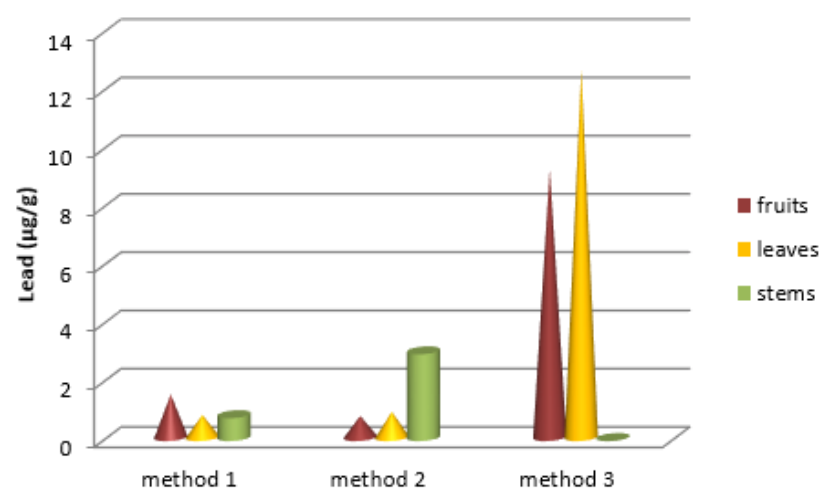

Fig.1. Lead content determined by the three methods

can act as ligands. These three cations have the property of being good complex combinations generators.

\section{Conclusions}

Ithas been found that although the plantstores especially large amounts of metal cations in leaves and fruits, all vegetative organs have the metal cations content within the limits of heavy metal concentrations allowed by F.R.X [23].

In conclusion, atomic absorption spectrometry is a simple, easily accessible method with high specificity and sensitivity. This method can be successfully applied in determining the content of metallic cations in plants, as long as the sample mineralization process is complete.

\section{References}

1. AMZOIU, E., ANOAICA, P.G., AVERIS, L.M.E., SIMIONESCU, A., BUBULICA, M.V., Rev. Chim.(Bucharest), 65, no.9, 2014, p. 1072 2. CIULU-COSTINESCU, F., CHIFIRIUC, M.C., POPA, M., BLEOTU, C., NEAMTU, J , AVERIS, L.M.E., BUBULICA, M.V., SIMIONESCU, A., ALDEA, I.M., BELU, I., Rev. Chim.(Bucharest), 66, no. 9, 2015, p.1266 3. BALASOIU, M.L., CALINA, D., VLASE, L., BUBULICA, M.V., CHIRIGIU, L., Rev. Chim.(Bucharest), 65, no.3, 2014, p.290
4. BUBULICA, M.V., ANGHEL, I., GRUMEZESCU, A.M., SAVIUC, C., ANGHEL, G.A., CHIFIRIUC, M.C., GHEORGHE, I., LAZAR, V., POPESCU, A., Farmacia; 60, nr.1, 2012, p. 80

5. TUZLACI, E., TOLON, E., Fitoterapia, 71, 2000, p.673

6. EBRAHIMZADEH, M.A., MAHMOUDI, M., POURMORAD, F., SAEIDNIA, S., SALIMI, E., MAZANDARAN, J., Uni. Med. Sci., 16, nr.54, 2006, p. 35 7.EBRAHIMZADEH, M.A., NABAVI, S.F., NABAVI, S.M., Pakistan. J. Biol. Sci., 12, nr. 5, 2009, p.447

8. SAEEDI SARAVI,S.S., SHOKRZADEH, M., Toxicol. Lett., 189, 2009, p.166

9. VANE, JR., BOTTING, R.M., Thromb. Res., 110, 2003, p. 255

10. FONSATTI, E., ALTOMONTE, M., ARSLAN, P., MAIO, M., 4, nr. 4, 2003, p. 291

11. WROBEL, K., WROBEL, K., URBINA, E., Biol. Trace Elem. Res., 78, 2000, p. 271

12. MIHUCZ, V.G., TATAR, E., KMETHY, B., ZARAY, G., CSEH, E.J., Inorg. Biochem., 81, 2000, p. 81

13. FLORES, M., SAIDELLES, A., MATTOS, J., MULLER, E., Int. J. Environ. Anal. Chem., 89, 2009, p. 129

14. MITITELU, M., IONITA, C., MOROSAN, E., Farmacia, 62(3), 2014, p. 618

15. IOVA, A., MICLE, O., VICAS, L., et al. Farmacia, 62(3), p. 539

16. UDEANU, D.I., IONITA, C., DOGARU, E., et al., Farmacia, 59(5), p. 611

17. JOHANSSON, L., MILLERPODRAZA, H., Anal Biochem., 265 , nr. 2, 1998 , p. 260

18. POPA, T., BUBULICA, M.V., CHIRIGIU, L., MOGOSANU, G. D., POPESCU, R., POPESCU, H., Curr Health Sci J., 36, nr. 2, 2010, p. 111 19. MOGOSANU, G.D., POPESCU, F.C., BUSUIOC, C. ., POP, O.T., MOGOANTÃ, L., PARVANESCU, H., RAU, G., LASCAR, I, Farmacia, 2014, 62(4) p. 702

20. STEPONENIENE, L., TAUTKUS, S., KAZLAUSKAS, R., Chemija, 14, nr. 2, 2002, p.99

21. OKWU, D.E., JOSIAH, C., Afr. J. Biotechnol., 5, nr. 4, 2006, p. 357 22. CHIRIGIU, L., POPESCU, R., BUBULICA, M.V., POPESCU, A., Rev. Chim.(Bucharest), 63, no.9, 2012, p. 874

23. *** Farmacopeea Romana editia a X-a, Ed. Medicala, Bucuresti, 1993.

Manuscript received: 11.03 .2019 